\title{
Information inequality during the implementation of the educational process among students of higher education institutions during the quarantine period in 2020-2021
}

\author{
I. Semenov \\ Vinnytsia Mykhailo Kotsiubynskyi State Pedagogical University \\ Corresponding author. E-mail: semenove595@gmail.com
}

Paper received 05.11.21; Accepted for publication 22.11.21.

\author{
https://doi.org/10.31174/SEND-PP2021-259IX101-09
}

\begin{abstract}
The purpose of this article is to reveal the concept of "information inequality", to investigate the data collected through anonymous questionnaires among students of higher education institutions in Vinnytsia sity. Owing to the questionnaire, information was obtained and analyzed regarding the equal access of higher education students to modern digital technologies, which were used to ensure the educational process during the implementation of distance education during the quarantine period.
\end{abstract}

Keywords: distance education, digital divide, online services, information inequality, distance learning.

Formulation of the problem. The transition of educational institutions for the period of quarantine to exclusively distance learning has raised a number of questions, to what extent are full-time students of Vinnytsia higher education institutions on equal terms regarding the technical support of distance learning? As far as students have equal skills to master and effectively use the relevant software product, a variety of online services used in distance learning. To what extent economic inequality among students affects the equality of conditions for the implementation of distance learning.

The analysis of previous research shows that the issue of information inequality in their research has attracted the attention of a number of scientists, in particular: L. Horodenko, Ya. Nilsen, V. Zhuravskoho ta M. Rodionova, M. Zahurovskyi.

The purpose of the article is to analyze the current situation regarding information inequality, opportunities for students of higher education institutions in Vinnytsia, to implement the educational process with the help of distance education tools during the quarantine period.

Presentation of the main material. The term "digital divide" or its synonyms "inequality" was first publicly used by former US President Bill Clinton in 1999 to describe the different opportunities for Americans to access the information infrastructure and to define a national strategy for the transition to the information society [1].

In scientific literature, problems associated with unequal access to modern information technology are combined with the term "digital divide". The term came into general use in the United States in the mid-1990s and was originally used to denote the gap between different social groups in the ability to buy a computer.

The works of Ukrainian researchers use different variants of the translation of the term "digital divide", namely: the digital abyss, the digital barrier, the digital divide, the digital distribution, etc. The translation of this term has a great variety of interpretations. However, the phrase "digital inequality" is most often used. Thus, in the book by $\mathrm{V}$. Zhuravskyi, M. Rodionova, I. Zhyliaieva "Ukraine on the way to the information society" the most common phrase is "digital inequality" [2].

Jakob Nielsen defines this phenomenon as a state when "a certain part of the population has significantly better opportunities to benefit from the use of modern technologies than the rest of the population" [3].

J. Nielsen identifies 3 types of digital inequality (Economic Divide, Usability Divide and Empowerment Divide) [3].

The first type is the definition of economic inequality in the original sense of the term, it shows an inequality in which a certain part of the population cannot afford to buy a computer.

The second type of inequality is that even with a computer, some cannot use it because most of the available services are too heavy for this group of users to understand.

J. Nielsen connects the third type of inequality with the fact that even if the computer and the Internet are extremely easy to use, not everyone will take full advantage of the latest technologies.

The classification of information inequality is defined by M. Zghurovskyi, considers the social component of the problem of information inequality. The scientist formed three dimensions of inequality:

The first concerns the uneven distribution of Internet sites in the regions of the world compared to the population distribution and reaches two, and sometimes three, orders of magnitude.

The second dimension of inequality is that $80 \%$ of the world's information and software product is created in English today, while $75 \%$ of the world's population does not speak it.

The third dimension concerns information inequality within individual countries: technological changes lead to the fact that some groups of the population, which have already been deprived of the modern benefits of civilization, are separated from the elite of the population even more [4].

O. Kyslova researched monopolistic tendencies in the information sphere, which influence the development of information inequality among countries. In her speech at the third congress of the Sociological Association of Ukraine, the scientist noted as an example that hardware developers provide for the possibility of their systems only if certain software is used, and existing licensed operating systems, in turn, do not allow to abandon unnecessary applications without violation license agreement and customize the operating system (you can only choose the interface). All this leads to an increasing consumption of information goods and services, the owners and suppliers of 
which are all the same leading countries. It becomes obvious that monopolistic tendencies are emerging in the information sphere, and the very possibility of a technological breakthrough in countries with "catching up" informatization is questionable [5].

S. Danylenko emphasizes, "all developers of new information technologies, which will then be used by multimedia, focused on the profitability of the project, on economic and political goals" [6].

As a result, the differential economic opportunities of different people give them access to different quality and capabilities of the software product and digital technology they use.

The study on information inequality among students of higher educational institutions in the city of Vinnytsia was conducted through a secret questionnaire, which was attended by 562 full-time students.

To the first question, regarding the availability of digital computer technology in the property, where the student had the opportunity to choose several answer options simultaneously, the following results were obtained:

- A personal computer is owned by 147 people among the surveyed respondents, which is $26.2 \%$;

- Laptops are owned by 397 people, which is $70.6 \%$ of respondents;

- The tablet is owned by 77 people among the participants in the survey, which is $13.7 \%$ of respondents;

- 525 people own a smartphone, which is $93.4 \%$ of respondents;

- The rest was mentioned by 15 people, which is $2.7 \%$ of respondents;

The second question - if you have a smartphone, specify the operating system installed on it.

- 75.6\% of respondents mentioned Android;

- $20.8 \%$ of respondents mentioned IOS;

$-2.1 \%$ of respondents mentioned Windows;

- $1.4 \%$ of surveyed students said otherwise.

These results show that when developing a variety of mobile applications for use in the educational process, you first need to focus on the Android operating system.

The next question examined the technical condition of digital technology, which is owned by the surveyed students in accordance with the needs of distance learning.

Only $27.2 \%$ of respondents stated that the digital equipment they own fully satisfies the needs of distance learning;

Almost completely satisfied were $31 \%$ of respondents;

Partially satisfies $31.3 \%$ of respondents;

$10.5 \%$ of respondents did not satisfy;

As a conclusion, in relation to this question it is possible to consider the answers of $41.8 \%(31.3 \%+10.5 \%)$ of students surveyed as such that the technical condition of digital technology does not meet the requirements for quality technical support of distance learning. This is a very large and threatening figure.

The next question was to find out the quality of Internet traffic.

High quality of Internet communication was noted by $19.2 \%$ of respondents;

The average quality of Internet communication was stated by $53.9 \%$ of respondents;

Insufficient quality was identified by $18.9 \%$ of respondents;
$8 \%$ of respondents mentioned low quality;

The results show that during distance learning $26.9 \%$ $(18.9 \%+8 \%)$ of the surveyed students are not able to fully participate in the learning process due to insufficient quality of Internet traffic.

The next question aimed to compare the results of the quality of Internet traffic and the type of settlement where the respondents live.

$41.8 \%$ of respondents live in the village;

In urban-type settlements $-10.7 \%$ of respondents;

In the city of regional significance $-8.4 \%$ of respondents;

In the city $-39.1 \%$ of respondents;

Formulating the questions for the questionnaire, we assumed that the number of students who will indicate in the questionnaire about the insufficient or low quality of the Internet will coincide with the percentage of students living in rural areas. However, $52.5 \%$ of respondents live in rural and urban-type settlements, and $26.9 \%$ of respondents reported the lack of Internet quality in the survey. This may indicate an increase in Internet coverage and an improvement in the mobile network. Exactly $93.4 \%$ of respondents to the first question answered that they own a smartphone.

The next issue concerned the ability of digital technology available to support distance learning.

"Fully supports the program load" said $34.3 \%$ of respondents;

$42.2 \%$ of respondents answered "not always";

$21.7 \%$ of respondents indicated "partially supports";

$1.8 \%$ of respondents said "does not support".

Only $34.3 \%$ of respondents own digital equipment that fully meets the requirements of the software used during distance learning.

The purpose of the next question is to determine the impact of the socio-economic situation in the country on the surveyed students regarding the possibility of overcoming information inequality in terms of modern technical support. The question was: "Do you have the financial means to purchase new modern computer equipment for personal work?".

$10 \%$ of respondents can buy modern computer equipment for personal work within a month;

Within six months $-12.8 \%$ of respondents;

During the year, $17.3 \%$ of respondents have the opportunity;

Purchase within two years $-12.3 \%$ of respondents;

$47.7 \%$ of respondents said they do not have the financial means to buy modern computer equipment.

It is a very threatening result against the background of how quickly a new software product is created, which requires more computing power, and how quickly digital technology becomes obsolete, given such a pace of development.

The fact that $47.7 \%$ of students who took part in the survey do not have the financial capacity at all and, as a result, do not consider its acquisition in the near future, only states the severity of socio-economic conditions in which 60 percent $(47,7 \%+12.3 \%)$ of respondents.

The following answers were given to the question "how do you assess the level of complexity of setting up and working with the software used for distance learning":

A high level of complexity was noted by $8.9 \%$ of respondents; 
$22.1 \%$ of respondents answered above average;

Average $-46.4 \%$ of respondents;

$14.2 \%$ of respondents indicated below average;

A low level of difficulty was determined by $8.4 \%$ of the surveyed students.

For $31 \%(8.9 \%+22.1 \%)$ of the survey participants, setting up and using a software product used for distance learning is a challenge and can only mean that either these students have insufficient skills to work with modern digital technology, or this result is affected by the unsatisfactory condition of the owned digital equipment, as noted by $41.8 \%$ of respondents.

The language used could also be a problem in setting up the software product. In most cases, software developers use English.

The following question was aimed at finding out whether there are problems with knowledge of foreign languages when setting up the software used to implement distance learning:

"Never" was mentioned by $36.1 \%$ of respondents;

"Very rarely" indicated $34.5 \%$ of respondents;

"Sometimes" 36.1\% of respondents answered;

"Quite often" was identified by 7.7\% of respondents;

"Very often" said $1.4 \%$ of respondents.

The following result was obtained when asked to "assess the level of your computer skills":

$2.7 \%$ of respondents rated themselves as having an initial level;

$6.9 \%$ of respondents said they were below average;

$38.4 \%$ of respondents rated themselves as having an average level;

$35.9 \%$ of respondents think that they have a level above the average;

$16 \%$ of respondents mentioned a high level.

After processing the results of anonymous testing, an additional survey was conducted among students of Vinnytsia universities. Its purpose was to supplement the information already received with the services provided by survey participants using ISPs, the cost of receiving Internet traffic per month, and whether there is enough Internet traffic to provide distance learning in accordance with educational requirements. The additional survey was attended by 158 students of higher educational institutions of the city of Vinnytsia, who were participants in a previously conducted survey of 562 students.

They were asked a number of questions.

What type of internet connection do you use?

$56.9 \%$ of surveyed students said that they use unlimited cable Internet

$24.1 \%$ use mobile limited internet

$10.4 \%$ use cable limited internet

$8.6 \%$ mobile unlimited internet

When asked if you have enough Internet traffic within the monthly package for distance learning, the following results were obtained:

$67.2 \%$ of respondents said Yes, enough;

$32.8 \%$ of respondents answered No, not enough.

In the previous question, data were obtained that $65.5 \%$ of students who took part in the additional survey use unlimited Internet.

From the results we can conclude that the amount of monthly traffic for distance learning is not enough for those students who do not have the opportunity to provide an unlimited package of Internet services.

In response to the question of how many users with you use the line to connect to the Internet received the following information:

$22.4 \%$ of respondents chose the answer Nobody but me;

$51.7 \%$ indicated up to three people inclusive;

$22.4 \%$ mentioned 4-6 people in the answer;

$3.5 \%$ of respondents mentioned more than 6 people.

The result shows that $25.9 \%(22.4 \%+3.5 \%)$ have some restrictions on access to the Internet during distance learning.

The following answers were received to the question of how much you pay per month for access to the Internet:

Up to 100 hryvnias per month $-3.4 \%$ of respondents;

From 100 to 150 hryvnias per month $-13.8 \%$ of respondents;

From 150 to 200 hryvnias per month $-46.6 \%$ of respondents;

$36.2 \%$ of respondents spend more than 200 hryvnias a month.

An additional survey found that there was a lack of Internet traffic to provide distance learning. $32.8 \%$ of students say that they do not have enough available Internet traffic for distance learning. In need of increasing the amount of Internet traffic to provide distance learning, students only state the problem, however, given the already significant period of study in quarantine regarding the date of the additional survey, do not solve it by increasing the amount of Internet traffic to the level required for quality distance learning.

This can mean only one thing - an increase in traffic will increase the funds needed to obtain it, but $17.2 \%$ of surveyed students can not afford to spend on access services and Internet use more than 150 hryvnias per month.

Conclusion. A study conducted among students of higher educational institutions in the city of Vinnytsia showed the existence of issues related to the concept of information inequality. The obtained results testify to the further deepening of this issue. The impact of the socio-economic situation in the country on the level of opportunities among students to have access to modern computer technology, to be able to receive educational information in a timely manner and to be fully involved in educational processes comes to the fore. Among researchers, information inequality is seen as a lack of relevant knowledge and skills, when one person, due to their own skills in using computer technology, knowledge of foreign languages, gets certain advantages over those who do not have such skills or do not have such a high level. This study brings to the fore another issue - the availability of the opportunity to obtain relevant skills and knowledge. Among students, $41.8 \%$ said that the technical condition of their digital technology is unsatisfactory. At the same time, 47.7 percent of students determined that they do not have the financial ability to purchase new modern digital technology for more than two years. During the implementation of distance learning $32.8 \%$ of students lack a monthly package of Internet traffic, this is despite the fact that the Internet is the bridge that connects during distance learning teacher and student.

It can be stated that during the transition to distance learning during the introduction of quarantine there was a situation when a significant number of students were not 
able to receive educational information in full due to the fact that their personal computer equipment did not meet the requirements for high-quality distance learning.

Every year, a large number of different educational software products are developed, which set new requirements for digital technology, require more computing power. How to use this software educational product in the educational process if $47.7 \%$ of students who took part in the survey do not have the financial means to buy a modern computer.

The immediate transition to distance learning clearly showed the problem of information inequality among students of higher education, which was not so noticeable during classroom learning.

\section{ЛИТЕРАТУРА}

1. Цифрова та інформаційна нерівність у мережевій комуні- $\quad$ 4. Згуровский М.3. Путь к информационному обществу - от кації / Л.М.Городенко // Інформаційне суспільство. 2012. - Вип. 16. - С. 56-59. http://nbuv.gov.ua/UJRN/is_2012_16_12

2. В.С.Журавський, М.К. Родіонов, І.Б.Жиляєв. Україна на шляху до інформаційного суспільства / В.С.Журавський, М.К. Родіонов, І.Б.Жиляєв; За заг. ред. М.З. Згуровського. - Київ.: ІВЦ "Політехніка", 2004., - 484 с.

3. Jakob Nielsen Digital Divide: The Three Stages // NielsenNormanGroup, 2006 -https://www.nngroup.com/articles/digitaldivide-the-three-stages/ Женевы до Туниса / Згуровский М.3. // Зеркало недели. 2005. - №34 (562). - C. 4-5.

5. Кислова О. М . «Великі дані» як чинник інформаційної нерівності / Кислова О. М. // Тези доповідей та виступів учасників III Конгресу Соціологічної асоціації України «Нові нерівності - нові конфлікти: шляхи подолання» - Харків, 12-13 жовт. - $2017 \mathrm{p}$.

6. Даниленко С. Тенденції розвитку електронних ЗМІ // Нові медіа. - К.: СПД Рудницька А., 2009. - С. 38-41.

\section{REFERENCES}

1. Cyfrova ta informacijna nerivnistj u merezhevij komunikaciji [Digital and information inequality in network communication] / Ghorodenko L. M.// Information society. - 2002. - №16 - P.56-59

2. Ukrajina na shljakhu do informacijnogho suspiljstva [Ukraine on the way to the information society] / V.S. Zhuravsjkyj, M.K. Rodionov, I.B.Zhyljajev; Za zagh. red. M.Z. Zghurovsjkyj. - K.: IVC "Politekhnika", 2004. - 484 p.

3. Jakob Nielsen Digital Divide: The Three Stages // NielsenNormanGroup, 2006 -https://www.nngroup.com/articles/digitaldivide-the-three-stages/

4. Zgurovskiy M.Z. Put k informatsionnomu obshchestvu - ot Zhenevy do Tunisa [The path to the information society]//

Zerkalo nedeli. - 2005. - №34 (562). - P. 4-5.

5. Kyslova O. M. «Velyki dani» jak chynnyk informacijnoji nerivnosti. Tezy dopovidej ta vystupiv uchasnykiv III Konghresu Sociologhichnoji asociaciji Ukrajiny «Novi nerivnosti - novi konflikty: shljakhy podolannja» ["Big data" as a factor of information inequality. Abstracts of reports and speeches of the participants of the III Congress of the Sociological Association of Ukraine "New inequalities - new conflicts: ways to overcome"] - Kharkiv, 12-13 Oct. 2017).

6. Tendenciji rozvytku elektronnykh ZMI [Trends in electronic media development] / Danylenko S. // Novi media. - K.: SPD Rudnycjka A., 2009. - P. 38-41. 